\title{
GAS CHROMATOGRAPHY - MASS SPECTROMETRY ANALYSIS OF ESSENTIAL OIL COMPOSITION OF CLERODENDRUM SERRATUM L.: A TRADITIONAL PLANT OF INDIA
}

\author{
RAJ KUMAR TIWARI ${ }^{1 *}$, UDAYABANU $^{2}$, SILPI CHANDA ${ }^{3}$ \\ ${ }^{1}$ Department of Pharmacy, Sunder Deep Pharmacy College, Ghaziabad, Uttar Pradesh, India. ${ }^{2}$ Department of Pharmacy, Jaypee University \\ of Information Technology, Waknaghat, Solan, Himachal Pradesh, India. ${ }^{3}$ Department of Pharmacognosy, Faculty, NIET, Pharmacy \\ Institute, Greater Noida, Uttar Pradesh, India. Email: raj_t365@yahoo.com
}

Received: 23 March 2017, Revised and Accepted: 13 April 2017

ABSTRACT

Objective: Clerodendrum serratum (L.) belonging to family Verbenaceae, commonly known as Bharangi, is a popular plant across various communities of India. Gas chromatography-mass spectrometry (GC-MS) is a unique technique to prospect various volatile principles and semivolatile compounds.

Materials and Methods: The phytoconstituents present in the root of n-hexane extract were evaluated by GC-MS using Clarus 500 mass spectrometer.

Results and Discussions: A total of 15 constituents were identified and characterized from the roots of $C$. serratum L. All the 15 compounds were tabulated with their retention time, percentage peak area, molecular formula, molecular weight, and Chemical Abstracts Service number. Out of all the compounds, $60 \%$ comprises the oxygenated compounds. Compound hexadecanoic acid, methyl ester, and benzene, 1,3-bis(1,1-dimethylethyl) showed highest percentage about 6.5 and 74.9 , respectively.

Conclusion: This study showed the presence of 15 compounds ranging from alkane, alkene as longest chain along with ester, aromatic and nonaromatic hydrocarbons.

Keywords: Clerodendrum serratum, Gas chromatography-mass spectrometry technique, Phytoconstituents, Volatile principles.

(C) 2017 The Authors. Published by Innovare Academic Sciences Pvt Ltd. This is an open access article under the CC BY license (http://creativecommons. org/licenses/by/4. 0/) DOI: http://dx.doi.org/10.22159/ajpcr.2017.v10i7.18674

\section{INTRODUCTION}

Plant has been a big reservoir for humankind as well as other species for various fulfillments related to food and ailments, carrying huge amount of primary and secondary metabolites. The WHO clearly appraises the practice of traditional medicine, accounting for about $80 \%$ for primary health care [1]. Nature provides large degree of variation regarding the phytoconstituents present in it. Due to this, there has been large development in the area of extraction such as cold extraction, hot extraction, Soxhlet, and microwave-assisted extraction [2]. However, the extraction of essential oil and aromatic content has been done through various distillation procedures such as steam distillation, hydrodistillation, or combination of both $[3,4]$. Currently, gas chromatography-mass spectrometry (GC-MS) interface has been an advanced technique for the separation of aromatic content due to its sensitivity and specificity.

Clerodendrum serratum (L.) belonging to the family Verbenaceae, commonly known as Bharangi, is a popular indigenous plant to India. The plant is widely distributed across the globe ranging though various continents from Asia to Africa [2]. In Ayurveda, the plant is well known as Bharangi (Sanskrit) and commonly known as blue glory (English). As per the traditional claims, the roots are the potential source of drug for ailments such as asthma, body ache, bronchitis, cholera, dropsy, eye diseases, fever, inflammations, malaria, ophthalmia, snakebite, tuberculosis, ulcers, and wounds [5]. Traditionally, Bharangi has been reported for fever by the tribals of Bengal and Andhra Pradesh. It is also used in snakebite by the various communities of Orissa. In chhattisgarh, Bharangi is use for malarial fever and liver problems. Literature supports its use in respiratory disorders such as asthma in various states of India such as Maharashtra, Chhattisgarh, Andhra Pradesh, and Madhya Pradesh [6-11]. Literature revealed the pharmacological activity of Bharangi such as anti-inflammatory activity, antinociceptive activity, and hepatoprotective activity [12-14].
Phytochemical studies reveal the presence of secondary metabolites such as glycosides, steroids, alkaloids, and phenolic class of compounds. It has been found to contain ursolic acid, spinasterol, spinasteryl- $\beta$-Dglucopyranoside, $\beta$-sitosterol, sucrose (disaccharide), bauer-9-en3-one, and 5-hydroxy-7,4-dimethoxy flavones in the stem part [15]. Aerial part of the plant possesses bis(2-ethylhexyl) phthalate, hispulidin, serratumin A, acteoside, martynoside, serratumoside-A, and myricoside, whereas root was found to contain D-mannitol, stigmasterol, oleanolic acid, ferulic acid, lupeol, and ursolic acid [16]. Essential oil is supposed to have large market potential in today's herbal market and GC-MS is one of the most advanced techniques for its isolation and characterization [17]. GC-MS is one of the advanced techniques for identification of various metabolites such as long-chain hydrocarbons, alkanes, volatile, and semivolatile components [18].

Our objective of the study is to identify and characterize the volatile principles present in the root of Bharangi, which could be used as novel compounds for new drug development and quality control of plant.

\section{METHODS}

Collection and authentication of plant material

Roots of C. serratum L. was purchased from Faizabad (Uttar Pradesh). The taxonomical identification was done from Department of Agronomy, Aacharya Narendra Dev Agriculture Technical University, District Faizabad, Uttar Pradesh.

\section{Chemicals}

Chemicals were procured from Sigma-Aldrich Co., St. Louis, USA. All other chemicals/solvent adopted was of analytical grade.

\section{Extraction and isolation of essential oil}

Root part of C. serratum L was cut into small pieces, shade dried at room temperature for 15 days and subjected to grinding mill. Coarse powder 
obtained was further passed through sieve. $44.10 \mathrm{~g}$ of root powder was macerated with $30 \mathrm{ml}$ of hexane overnight followed by sonication for 15 minutes. Further, hexane extract was subjected to reflux for 2 hrs. Centrifugation was done for the refluxed sample for 10 minutes and kept in a sealed vial in the refrigerator $\left(4^{\circ} \mathrm{C}\right)$ until further use.

\section{Preparation of sample for GC/MS analysis}

A volume of $5 \mathrm{ml}$ of $\mathrm{n}$-hexane plant extract was vortexed properly, centrifuge for 5 minutes and filtered through $0.22 \mathrm{~mm}$ syringe filter (Millipore Corp., Bedford, MA, USA). $1 \mathrm{ml}$ aliquot of each sample solution was injected into the GC/MS system for the requisite analysis.

\section{Instrumentation and chromatographic conditions}

The phytoconstituents present in the n-hexane root extract was evaluated by GC-MS Clarus 500 mass spectrometer. Temperature programmed with a ramp $8^{\circ} \mathrm{C} / \mathrm{min}$ up to $240^{\circ} \mathrm{C}$ and $\operatorname{ramp} 6^{\circ} \mathrm{C} / \mathrm{min}$ up to $280^{\circ} \mathrm{C}$ hold for 15 minutes while the injector temperature kept at $280^{\circ} \mathrm{C}$ at injection volume of $1 \mu \mathrm{L}$ with a syringe size of $10 \mu \mathrm{L}$. Flow rate was maintained at $1.2 \mathrm{ml} /$ minutes. Oven was maintained for 70 minutes having transfer line temperature for about $280^{\circ} \mathrm{C}$. Scanning was done in the range of 35-500 amu. Identification of phytoconstituents was made by comparison of their mass spectra with NIST library mass spectra.

\section{RESULTS AND DISCUSSION}

GC/MS chromatograms of n-hexane root extract of $C$. serratum L. showed several peaks indicating the presence of a wide range of volatile principles. A total of 15 constituents were identified and characterized from the root of $C$. serratum $\mathrm{L}$. Table 1 listed all the identified chemicals along with their peak percentage, retention time, molecular weight, molecular formula, and Chemical Abstracts Service number. The structures of all the identified compounds are shown in Fig. 1a and b. Components were identified using the combination of retention index value and mass spectral matching against library standards.

\section{CONCLUSIONS}

In this study, a total of 15 phytoconstituents have been identified from $C$. serratum L. by GC/MS analysis. All the compounds have been reported for the first time from the plant. The presence of bioactive entities stakes the utilization of $C$. serratum. for various ailments in

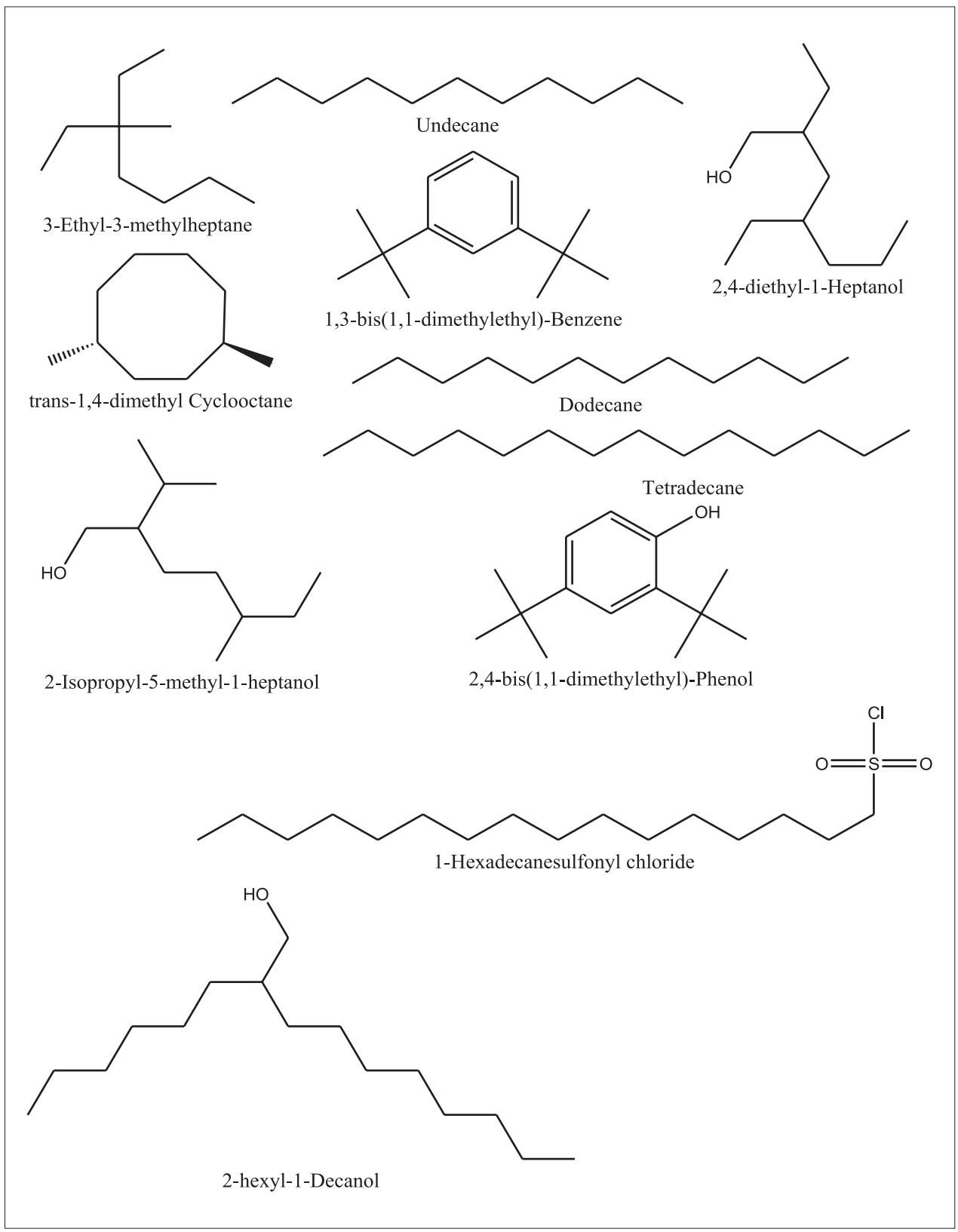

Fig. 1a: Identified phytoconstituents from roots of Clerodendrum serratum L. by gas chromatography-mass spectrometry technique 
Table 1: Identified volatile compounds from the root of $C$. serratum $\mathrm{L}$.

\begin{tabular}{|c|c|c|c|c|c|c|}
\hline $\begin{array}{l}\text { Peak RT } \\
\text { (minutes) }\end{array}$ & Compound detected & $\begin{array}{l}\% \text { Peak } \\
\text { area }\end{array}$ & $\begin{array}{l}\text { Molecular } \\
\text { formula }\end{array}$ & $\begin{array}{l}\text { Molecular } \\
\text { weight }\end{array}$ & CAS number & Activity reported \\
\hline 4.108 & 3-ethyl-3-methylheptane & 9.52 & $\mathrm{C}_{10} \mathrm{H}_{22}$ & 776 & $17302-01-01$ & $\begin{array}{l}\text { Biomarker for urinary cell } \\
\text { carcinoma [19] }\end{array}$ \\
\hline 5.054 & Undecane & 8.82 & $\mathrm{C}_{11} \mathrm{H}_{24}$ & 804 & $1120-21-4$ & Antimicrobial agent [20] \\
\hline 5.118 & 1-heptanol, 2,4-diethyl & 5.19 & $\mathrm{C}_{11}^{11} \mathrm{H}_{24} \mathrm{O}^{24}$ & 736 & $80192-55-8$ & Cosmetics $[21]$ \\
\hline 5.354 & Cyclooctane, 1,4-dimethyl-, trans- & 3.35 & $\mathrm{C}_{10}^{11} \mathrm{H}_{2} \mathrm{O}$ & 726 & 13151-98-99 & Vehicle hydrocarbon [22] \\
\hline 6.946 & Dodecane & 17.46 & $\mathrm{C}_{12}^{10} \mathrm{H}_{26}^{2}$ & 832 & $112-40-3$ & Oxygen vector [23] \\
\hline 8.688 & 2-isopropyl-5-methyl-1-heptanol & 3.71 & $\mathrm{C}_{11}^{14} \mathrm{H}_{24}^{22} \mathrm{O}$ & 761 & $91337-07-4$ & Antimicrobial [25] \\
\hline 10.171 & Tetradecane & 26.7 & $\mathrm{C}_{14}^{11} \mathrm{H}_{3}^{24} \mathrm{O}$ & 836 & $629-59-4$ & Biomedical use [26] \\
\hline 11.929 & Phenol, 2,4-bis (1,1-dimethylethyl)- & 35.1 & $\mathrm{C}_{14}^{14} \mathrm{H}_{22}^{3} \mathrm{O}$ & 880 & $96-76-4$ & Antioxidant [27] \\
\hline 12.232 & 1-hexadecanesulfonyl chloride & 4.97 & $\mathrm{C}_{16}^{14} \mathrm{H}_{33}^{22} \mathrm{ClO}_{2} \mathrm{~S}$ & 722 & $38775-38-1$ & Antifungal and Antioxidant [28] \\
\hline 12.500 & 1-decanol, 2-hexyl- & 4.68 & $\mathrm{C}_{16}^{16} \mathrm{H}_{34}^{33} \mathrm{O}^{2}$ & 734 & $2425-77-6$ & Commercially used [29] \\
\hline 15.614 & Fumaric acid, dodecyl 2-methylallyl ester & 9.19 & $\mathrm{C}_{20}^{16} \mathrm{H}_{34}^{34} \mathrm{O}_{4}$ & 562 & & Not reported \\
\hline 15.791 & $\begin{array}{l}\text { 7H-cyclohepta[a] naphthalen-7-one, } \\
\text { 8,9,10,11-tetrahydro-9,9-dimethyl- }\end{array}$ & 26.7 & $\mathrm{C}_{17}^{20} \mathrm{H}_{18}^{34} \mathrm{O}^{4}$ & 547 & $64184-19-6$ & Not reported \\
\hline 19.537 & $\begin{array}{l}\text { 9,12-Octadecadienoic acid (Z, Z)-, methyl } \\
\text { ester }\end{array}$ & 13.8 & $\mathrm{C}_{19} \mathrm{H}_{34}^{34} \mathrm{O}_{2}$ & 867 & $112-63-0$ & Anticancer activity [30] \\
\hline
\end{tabular}

CAS: Chemical abstracts service

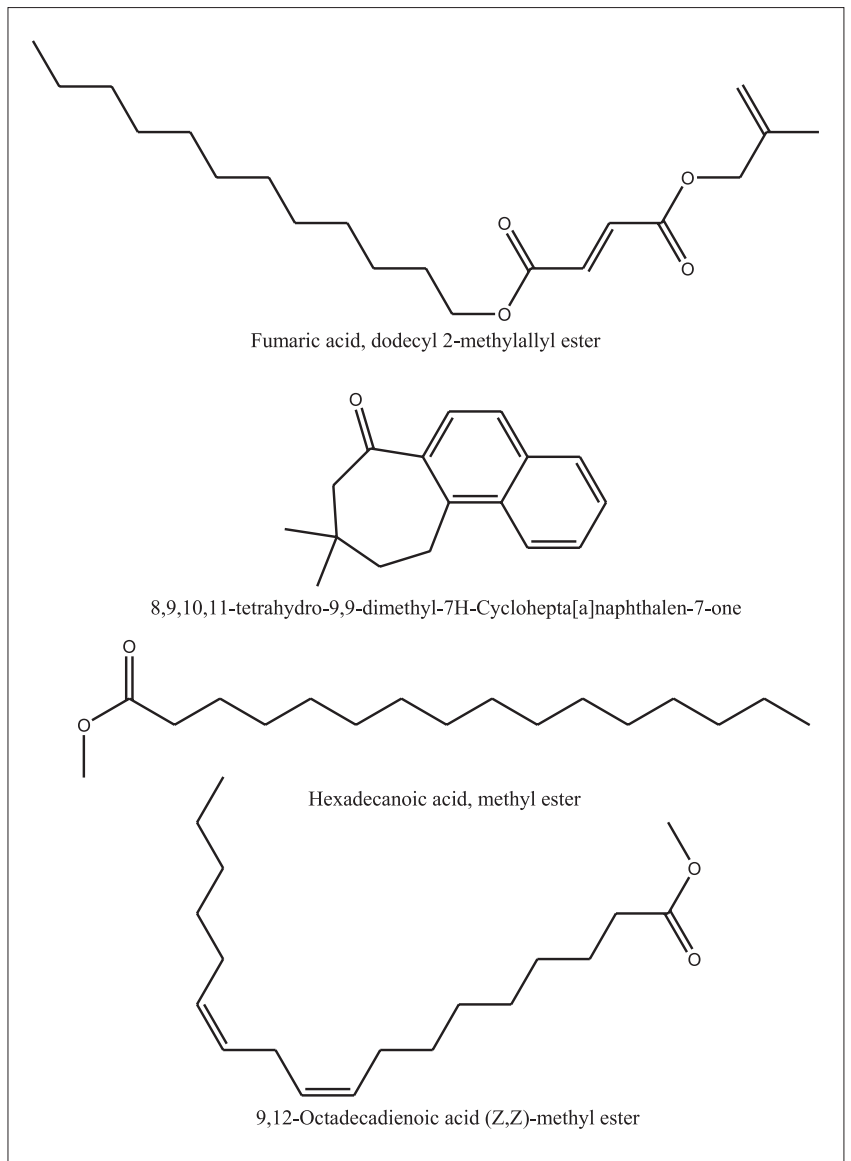

Fig. 1b: Identified phytoconstituents from roots of Clerodendrum serratum $\mathrm{L}$. by gas chromatography-mass spectrometry technique

traditional system of medicine. The plant contains several bioactive phytoconstituents, and further study is needed to discover and establish bioactivity for various compounds present in the plant. This study provides a scientific basis for the traditional use of plant as well as documents volatile principles present in it. Volatile oil is found to have biological significance with antibacterial, antifungal, antiseptic property, etc. Bharangi has a wide range of medicinal value in regard to the constituents identified. Compound hexadecanoic acid and methyl ester showed highest percentage of about 76.5 having medicinal value of antibacterial and antifungal property, whereas benzene, 1,3-bis(1,1dimethylethyl) was found to be $74.9 \%$ having lipid oxidation activity. Other compounds identified were having antimicrobial, anticancer, cosmetic, and commercial value. Moreover, the method can also be used as quality control measure for Bharangi plant.

\section{REFERENCES}

1. Kosalge SB, Fursule RA. Investigation of ethnomedicinal claims of some plants used by tribals of Satpuda Hills in India. J Ethnopharmacol 2009;121(3):456-61.

2. Patel JJ, Acharya SR, Acharya NS. Clerodendrum serratum (L.) Moon. - A review on traditional uses, phytochemistry and pharmacological activities. J Ethnopharmacol 2014;154(2):268-85.

3. Pallado PP, Tassinato G, Alpaos DD, Traldi PP. Gas chroma-tography/ mass spectrometry in aroma chemistry: A comparison of essential oils and flavours extracted by classical and supercritical techniques. Rapid Commun Mass Spectrom 1997;11:1335-41

4. Iordache A, Culea M, Gherman C, Cozar O. Characterization of some plant extracts by GC-MS. Nucl Instrum Methods Phys Res B 2009;267:338-42.

5. Ghosh T, Maity KT, Sengupta P, Dash KD, Bose A. Antidiabetic and in vivo antioxidant activity of ethanolic extract of Bacopa monnieri L. aerial parts: A possible mechanism of action. Iranian J Pharm Res 2008;7:61-8

6. Padal SB, Murty PP, Rao DS, Venkaiah M. Ethnomedicinal plants from Paderu division of Visakhapatnam district, A.P, India. J Phytol 2010;2:70-91.

7. Korpenwar AN. Ethnomedicinal plants used by Bhilala tribals in Buldhana District (M. S.) DAV. Int J Sci 2012;1:60-5.

8. Sahu CR, Nayak RK, Dhal NK. The plant wealth of Boudh district of Odisha, India with reference to ethnobotany. Int J Curr Biotechnol 2013;1:4-10.

9. Jain SP, Singh J. Traditional medicinal practices among the tribal people of Raigarh (Chhatisgarh), India. Indian J Nat Prod Resour 2010;1:109-15.

10. Padal SB, Raju JB, Chandrasekhar P. Traditional knowledge of Konda Dora tribes, Visakhapatnam district, Andhra Pradesh, India. IOSR J Pharm 2013;3:22-8.

11. Wagh VV, Jain AK. Ethnomedicinal uses of underground plant parts in Jhabua district of Madhya Pradesh, India. Adv Biol Res 2014;8:151-6.

12. Jain JB, Kumane SB, Bhattacharya S. Medicinal flora of Madhya Pradesh and Chattishgarh. IJKT 2016;5:237-42.

13. Sinha MK, Sinha D. Herbal medicinal plants of Koria district (C.G.) India. Int J Green Herb Chem 2013;2:1114-20.

14. Gupta AK, Tandon N, Sharma M. Review on Indian Medicinal Plants. Vol. 7. New Delhi: Indian Council of Medical Research; 2008. p. 127. 
15. Vidya SM, Krishna V, Manjunatha BK, Mankani KL, Ahmed M, Singh SD. Evaluation of hepatoprotective activity of Clerodendrum serratum L. Indian J Exp Biol 2007;45(6):538-42.

16. Kumar P, Niteshwar K. Phytochemical and pharmacological profiles of clereodendrum serratum. Int J Res Ayurveda Pharm 2013;4:276-8.

17. Kumar SS, Samydurai P, Ramakrishnan R, Nagarajan N. Gas chromatography and mass spectrometry analysis of bioactive constituents of adiantum Capillus-veneris L. Int J Pharm Pharm Sci 2014;6:60-3

18. Saravanan P, Chandramohan G, Mariajancyrani J, Shanmugasundaram P. Gc-Ms analysis of phytochemical constituents in ethanolic bark extract of Ficus religiosa Linn. Int J Pharm Pharm Sci 2014;6:457-60.

19. Wang D, Wang C, Pi X, Guo L, Wang Y, Li M, et al. Urinary volatile organic compounds as potential biomarkers for renal cell carcinoma. Biomed Rep 2016;5(1):68-72.

20. Gibka J, Styczyńska AK, Gliński M. Antimicrobial activity of undecan-3- one, undecan-3-ol and undec-3-yl acetate. Exp Immunol 2009;34:154-7.

21. Lide DR. Handbook of Chemistry and Physics. $65^{\text {th }}$ ed. Cleveland, Ohio: CRC Publishers; 1984

22. Moinuddin S, Mohammad MR, Mohammed M. New alternative veichle hydrocarbon liquid fuels from municipal solid waste plastics. J Fundament Renew Energy Appl 2011;1:1-9.

23. Jianlong W. Enhancement of citric acid production by Aspergillus niger using n- dodecane as an oxygen-vector. Proc Biochem 2000;35:1079-83.

24. Li C, He L, Jin G, Ma S, Wu W, Gai L. Effect of different irradiation dose treatment on the lipid oxidation, instrumental color and volatiles of fresh pork and their changes during storage. Meat Sci 2017;128:68-76.

25. Muthulakshmi A, Margret RJ, Mohan VR. GC-MS analysis of bioactive components of Feronia elephantum correa (Rutaceae). J Appl Pharm Sci 2012;2:69-74.

26. Rapp BE, Carneiro L, Länge K, Rapp M. An indirect microfluidic flow injection analysis (FIA) system allowing diffusion free pumping of liquids by using tetradecane as intermediary liquid. Lab Chip 2009;21:354-6.

27. Prakash A, Suneetha V. Punica granatum (Pomegranate) rind extract as a potent substitute for lascorbic acid with respect to the antioxidant activity. Res J Pharm Biol Chem 2014;5:597-603.

28. Hirapara DG, Gajera HP, Bhimani RD, Golakiya BA. The SRAP based molecular diversity related to antifungal and antioxidant bioactive constituents for biocintrol potentials of Trichoderma against sclerotium rolfsii Scc. Curr Genet 2016;62619-41.

29. Gao Y, Tu W, Chen Z, Tian Y, Liu R, Wang LM. Dielectric relaxation of long-chain glass-forming monohydroxy alcohols. J Chem Phys 2013;139:164504

30. Abubakar MN, Majinda RR. GC-MS analysis and preliminary antimicrobial activity of Albizia adianthifolia (Schumach) and Pterocarpus angolensis (DC). Medicines 2016;3:1-9. 